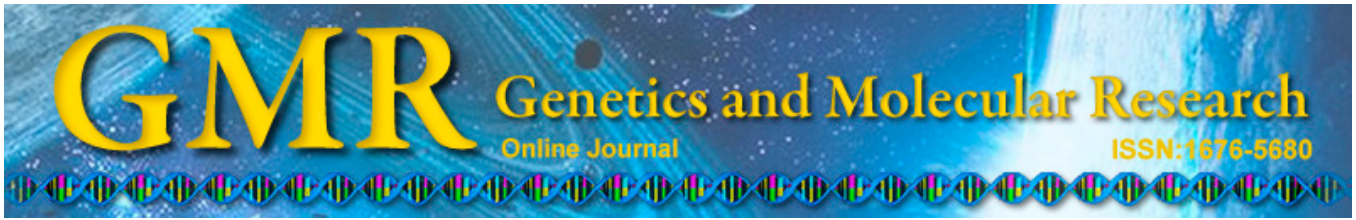

\title{
Evaluation of pH effects on genomic integrity in adipose-derived mesenchymal stem cells using the comet assay
}

L.C. Hermeto ${ }^{1,2}$, R J. Oliveira ${ }^{2,3,4}$ R. Matuo ${ }^{2,3}$, P.H.A. Jardim ${ }^{5}$ R. DeRossi ${ }^{5}$ A.C.M.B. Antoniolli ${ }^{2,4}$, E. Deffune ${ }^{6}$, T.C. Evaristo $^{6}$ and Á.E. Santana ${ }^{1}$

${ }^{1}$ Programa de Pós Graduação em Cirurgia Veterinária,

Faculdade de Ciências Agrárias e Veterinárias, Universidade Estadual Paulista, Jaboticabal, SP, Brasil

${ }^{2}$ Centro de Estudos em Células-Tronco, Terapia Celular e Genética Toxicológica, Núcleo de Hospital Universitário, Universidade Federal de Mato Grosso do Sul, Campo Grande, MS, Brasil

${ }^{3}$ Programa de Mestrado em Farmácia, Centro de Ciências Biológicas e da Saúde, Universidade Federal de Mato Grosso do Sul, Campo Grande, MS, Brasil

${ }^{4}$ Programa de Pós-Graduação em Saúde e Desenvolvimento na Região

Centro-Oeste, Faculdade de Medicina "Dr. Hélio Mandetta”,

Universidade Federal de Mato Grosso do Sul, Campo Grande, MS, Brasil

${ }^{5}$ Departamento de Cirurgia e Anestesiologia Veterinária,

Faculdade de Medicina Veterinária e Zootecnia,

Universidade Federal de Mato Grosso do Sul, MS, Brasil

${ }^{6}$ Laboratório de Engenharia Celular, Faculdade de Medicina de Botucatu,

Universidade Estadual Paulista, Botucatu, SP, Brasil

Corresponding author: R.J. Oliveira

E-mail: rodrigo.oliveira@ufms.br

Genet. Mol. Res. 14 (1): 339-348 (2015)

Received August 6, 2014

Accepted November 7, 2014

Published January 23, 2015

DOI http://dx.doi.org/10.4238/2015.January.23.7

ABSTRACT. The use of mesenchymal stem cells (MSCs) in experimental, clinical, and therapeutic trials has grown in recent years. However, the issue remains of whether these procedures are completely safe for transplant patients. Therefore, this study was designed and carried 
out with the aim of evaluating two different comet assay protocols for genomic damage pattern analysis in MSCs derived from adipose tissue. The analyzed and interpreted results suggest that genetic testing is needed to support clonal expansion safety in cell therapy procedures with MSCs. Furthermore, they also suggest that if the comet assay technique would be used as a genomic integrity screening assay, the protocol performed at $\mathrm{pH}=12$ (that yielded a frequency of damaged cells: tail intensity $=9.50 \pm 0.60$, tail moment $=0.0122 \pm 0.0007$; results are reported as means \pm standard deviation) would be indicated as genomic damage, and that subsequent single-strand breaks occur at $\mathrm{pH}>13$ (frequency of damaged cells: tail intensity $=30.71 \pm 4.23$, tail moment $=0.0447 \pm$ 0.0073). Our study demonstrates that, in the era of regenerative medicine, it is necessary to standardize and establish a battery of tests in order to identify genomic damage prior to MSC transplantation.

Key words: Mesenchymal stem cells; Comet assay; Adipose tissue

\section{INTRODUCTION}

Mesenchymal stem cells (MSCs) can undergo successive cell divisions and remain multipotent. They are also able to differentiate into mesenchymal tissue lineages, including bone, cartilage, tendon, muscle, fat, and bone marrow stroma (Pittenger et al., 1999). This capacity for clonal expansion without differentiation in a given tissue is an important feature that may, in the near future, ensure autologous and/or heterologous procedures in areas such as cell therapy, tissue engineering, regenerative medicine, and translational human and/or veterinary arenas. However, the literature has not adequately established how safe it is to maintain MSCs by successive clonal expansions in vitro, and/or utilize cryopreservation systems (Qin et al., 2009; Torsvik et al., 2010).

The research on easily accessible sources of MSCs led several groups to investigate cells from different tissues, including bone marrow (Mackay et al., 1998), cord blood, mobilized peripheral blood (Villaron et al., 2004), and adipose tissue (Zuk et al., 2001). Although a large number of stem cells can be isolated from adipose tissue, in vitro cell expansion is still required (Mesimäki et al., 2009), as the procedures require millions of cells. However, clonal expansion concerns the scientific community because the current literature includes studies in which authors have reported an increased risk of genetic instability, spontaneous transformation, and formation of in vivo malignant tumors (Froelich et al., 2013). Such reports raise the need for further studies in order to ensure the safety of cell therapy methods that are also more efficient, reliable, and sensitive for the detection of genomic damage in stem cells. On this basis, the current study aimed to evaluate two different comet assay protocols for the analysis of genomic lesions in MSCs derived from adipose tissue.

\section{MATERIAL AND METHODS}

\section{Animals}

A total of six adult New Zealand white rabbits weighing 3.0-4.0 kg, of both genders, were used in this study. The rabbits were kept in individual stalls equipped with burrows and 
nests in order to minimize distress, and were provided with water and feed (Presence Purina ${ }^{\circledR}$, São Paulo, Brazil) ad libitum. The experimental protocol was approved by the Ethics Committee on Use of Animals (CEUA) of Faculdade de Ciências Agrárias e Veterinárias, Universidade Estadual Paulista, under approval No. 027839/12. The experiment was conducted in accordance with the ethical principles adopted by the Brazilian College of Animal Experimentation (COBEA).

\section{Adipose tissue harvesting, isolation, and culture of MSCs}

For harvesting of adipose tissue, the rabbits were anesthetized with intramuscular administration of $30 \mathrm{mg} / \mathrm{kg}$ ketamine (Vetanarcol, König, São Paulo, Brasil) and $5 \mathrm{mg} / \mathrm{kg}$ xylazine (König) under aseptic conditions, a 1.0-2.0-cm incision was made between the scapulas, and the adipose tissue was removed from the subcutaneous space by divulsion; the incision was then closed with nylon sutures. After harvesting, the adipose tissue was washed three to four times with phosphate-buffered saline (Gibco, Life Technologies, Carlsbad, CA, USA) and then suspended in a Collagenase type II - Clostridium histolyticum (Gibco) solution [2 $\mathrm{mg}$ collagenase/mL HEPES medium (Gibco)], in the ratio $2 \mathrm{~mL}$ solution per gram adipose tissue, and maintained overnight at $37^{\circ} \mathrm{C}$ with $5 \% \mathrm{CO}_{2}$. After this period, enzyme activity was neutralized with Dulbecco's modified Eagle's medium Knockout (DMEM-Knockout) (Gibco) containing 10\% fetal bovine serum (FBS) (Gibco). The infranatant was centrifuged at 300 $g$ for $10 \mathrm{~min}$ at room temperature in order to pellet the cells, which were filtered to remove debris and seeded on tissue culture plates for culture and expansion. The cultures were maintained in DMEM-Knockout supplemented with $10 \%$ FBS and antibiotics-antimycotic solution $(10,000 \mathrm{U} / \mathrm{mL}$ penicillin, 10,000 U/mL streptomycin, and $25 \mathrm{U} / \mathrm{mL}$ amphotericin-B; Gibco) at $37^{\circ} \mathrm{C}$ with $5 \% \mathrm{CO}_{2}$. The culture medium was changed every two days. Upon achieving approximately $80 \%$ confluence, the cells were trypsinized ( $0.025 \%$ trypsin, Invitrogen) and plated at a density of $5000 \mathrm{cells} / \mathrm{cm}^{2}$; this was repeated each time the $80 \%$ confluence level was reached. The medium containing the suspended cells was transferred from the flask to a $15-\mathrm{mL}$ sterile tube and centrifuged at $300 \mathrm{~g}$ for $10 \mathrm{~min}$. The supernatant was aspirated and the cells were suspended in $1 \mathrm{~mL}$ culture medium. A $30-\mu \mathrm{L}$ aliquot was diluted in $30 \mu \mathrm{L}$ trypan blue (Gibco) for cell counting in a Neubauer chamber, in order to proceed to the cell viability assay. Posteriorly, remaining cells were divided into three sterile tubes; two were utilized for the comet assays, and the third for adipogenic, osteogenic, and chondrogenic differentiation.

\section{Adipogenic, osteogenic, and chondrogenic differentiation}

For the differentiation assay, cells were seeded into four plates at a density of $2 \mathrm{x}$ $10^{5}$ cells $/ \mathrm{cm}^{2}$ and in two sterile $15-\mathrm{mL}$ conical tubes at $1 \times 10^{6}$ cells $/ \mathrm{cm}^{2}$. Two plates and one tube were maintained in DMEM-Knockout supplemented with $10 \%$ FBS and antibiotics for use as controls. The cells for adipogenic and osteogenic differentiation were maintained for $24 \mathrm{~h}$ in DMEM as described above, and then the medium was replaced with that from the STEMPRO Adipogenic and Osteogenesis Differentiation Kit (Invitrogen). Cultures were maintained for 14 days, and the medium was changed every three days. The chondrogenic differentiation was performed as a three-dimensional pellet culture. Cells were maintained for $24 \mathrm{~h}$ in DMEM as described above, and then the medium was replaced by that from the STEMPRO Condrogenesis Differentiation Kit (Invitrogen), and maintained for 21 days. The medium was changed every three days. After the culture period, the medium was discarded and 
cells were fixed with 4\% paraformaldehyde for $1 \mathrm{~h}$. Adipogenic differentiation was confirmed by Oil Red O staining. Osteogenic differentiation was confirmed by Alizarin Red staining. The chondrogenesis differentiation pellets were subjected to routine histological processing and then stained by Toluidine Blue.

\section{Comet assays}

For detection of DNA damage, the comet assay was used in a $\mathrm{pH}>13$ alkaline version and at $\mathrm{pH}=12$ in samples from the same trypsinization so that this parameter did not influence the results, as previously described by Tice et al. (2000) and Villela et al. (2007). Cells were collected by trypsinization, and an aliquot was mixed with $20-120 \mu \mathrm{L} 0.75 \%$ low-melting point agarose at $37^{\circ} \mathrm{C}$ and layered onto a precoated slide with $1.5 \%$ regular agarose, and covered with a coverslip. After a brief agarose solidification in the refrigerator, the coverslip was removed and slides were immersed in lysis solution [2.5 M NaCl, $100 \mathrm{mM}$ ethylenediaminetetraacetic acid (EDTA), $10 \mathrm{mM}$ Tris-HCl buffer, $\mathrm{pH} 10,1 \%$ sodium sarcosinate with $1 \%$ Triton X-100, and $10 \%$ dimethyl sulfoxide], and maintained in the dark at $4{ }^{\circ} \mathrm{C}$ for $2 \mathrm{~h}$. For the $\mathrm{pH}>13$ alkaline version, the slides were left for $20 \mathrm{~min}$ in the electrophoresis buffer $(300 \mathrm{mM}$ $\mathrm{NaOH}, 1 \mathrm{mM}$ EDTA) and electrophoresed for another $20 \mathrm{~min}$ at $25 \mathrm{~V}$ and $300 \mathrm{~mA}$. For the $\mathrm{pH}$ 12 assay, the slides were left for $20 \mathrm{~min}$ in the electrophoresis buffer $(300 \mathrm{mM} \mathrm{NaOH}, 1 \mathrm{mM}$ EDTA, pH 12) and electrophoresed for another $20 \mathrm{~min}$ at $21 \mathrm{~V}$ and $270 \mathrm{~mA}$. After electrophoresis, the slides were neutralized with $0.4 \mathrm{M}$ Tris- $\mathrm{HCl}, \mathrm{pH}$ 7.5, for $15 \mathrm{~min}$ ( 3 times for $5 \mathrm{~min}$ each) and left to dry overnight. The slides were fixed in absolute ethanol for $10 \mathrm{~min}$ and stored until analysis. A total of 50 randomly captured comets from each slide were examined blindly at $400 \mathrm{X}$ magnification using a fluorescence microscope (Olympus, Tokyo, Japan) connected by a camera to an image analysis system (Comet Assay II, Perceptive Instruments, Haverhill, UK). In order to quantify the DNA damage, two image analysis system parameters were recorded: tail intensity and tail moment, and then statistically analyzed by the Student $t$-test $(\mathrm{P}<$ 0.05 was considered to be statistically significant).

\section{RESULTS}

\section{Cell number and cell viability estimation}

The average number of cells per culture flask was $2.28 \pm 0.24 \times 10^{6}$ and the average cell viability percentage was $96.33 \pm 0.61$.

\section{MSCs can differentiate in vitro into adipogenic, osteogenic, and chondrogenic cells}

The differentiated MSCs, obtained from rabbit adipose tissue and cultured in accordance with osteogenic, adipogenic, and chondrogenesis differentiation protocols, were confirmed by observation of the morphological changes typical of these cell types. Control cells were plastic-adherent and showed the typical spindle-shaped, fibroblast-like morphology (Figure 1A, C). Figure 1B shows red-stained calcium deposits validated by Alizarin Red dye, confirming osteogenic differentiation. Figure 1D shows cells with the typical intracellular, red-stained lipid vacuoles, which, in this case, were validated by Oil Red O dye. By comparing the control undifferentiated cells (Figure 1E) and those having undergone chondrogenic 
differentiation (Figure 1F), in this case confirmed by toluidine blue dye, it was possible to observe a marked difference between undifferentiated and differentiated cell pellets, wherein the differentiated pellet showed typical and abundant extracellular matrix.

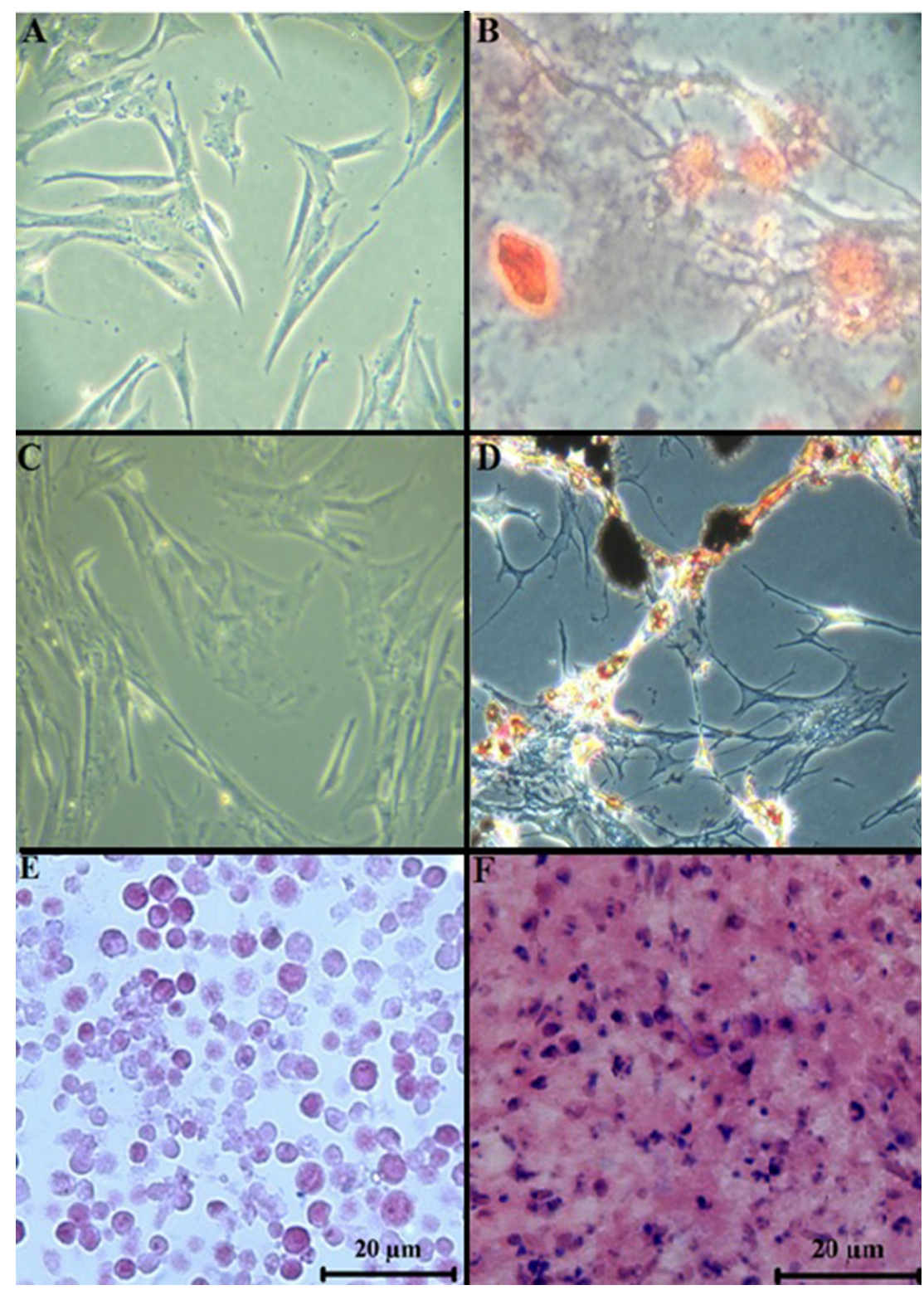

Figure 1. Morphological changes induced in adipogenic, osteogenic, and chondrogenic differentiation of mesenchymal stem cells. Cultures of adherent stem cells (A and $\mathbf{C}$ ), osteogenic differentiation (B), adipogenic differentiation (D), pelleted control stem cells $(\mathbf{E})$, and pelleted chondrogenic differentiation stem cells $(\mathbf{F})$. Images obtained using an inverted microscope at 20X magnification (A-D); images obtained in a brightfield microscope at 40X magnification $(\mathbf{E}$ and $\mathbf{F})$. 


\section{Evaluation of genotoxicity in MSCs}

In order to investigate and evaluate the DNA damage pattern in MSCs derived from adipose tissue, the comet assay was performed on undifferentiated cells in $\mathrm{pH}>13$ alkaline and $\mathrm{pH}=12$ protocol versions. Figure $2 \mathrm{~A}$ shows cells from the $\mathrm{pH}=12$ version, while Figure $2 \mathrm{~B}$ shows them from the $\mathrm{pH}>13$ version. Figure $2 \mathrm{C}$ shows a cell being analyzed by the software at $\mathrm{pH}=12$, whereas Figure $2 \mathrm{D}$ shows a cell being analyzed by the software at $\mathrm{pH}>$ 13. The results indicated that the protocol using a buffer at $\mathrm{pH}>13$ showed an average tail intensity value of $30.71 \pm 4.23$, whereas at $\mathrm{pH}=12$, the average value obtained was $9.50 \pm 0.60$ (Figure 2E). This reduction was highly significant $(\mathrm{P}=0.0006)$. A similar result was observed for tail moment (Figure 2F), with average values for the $\mathrm{pH}=12$ and $\mathrm{pH}>13$ protocol versions of $0.0122 \pm 0.0007$ and $0.0447 \pm 0.0073$, respectively $(\mathrm{P}=0.0013)$.
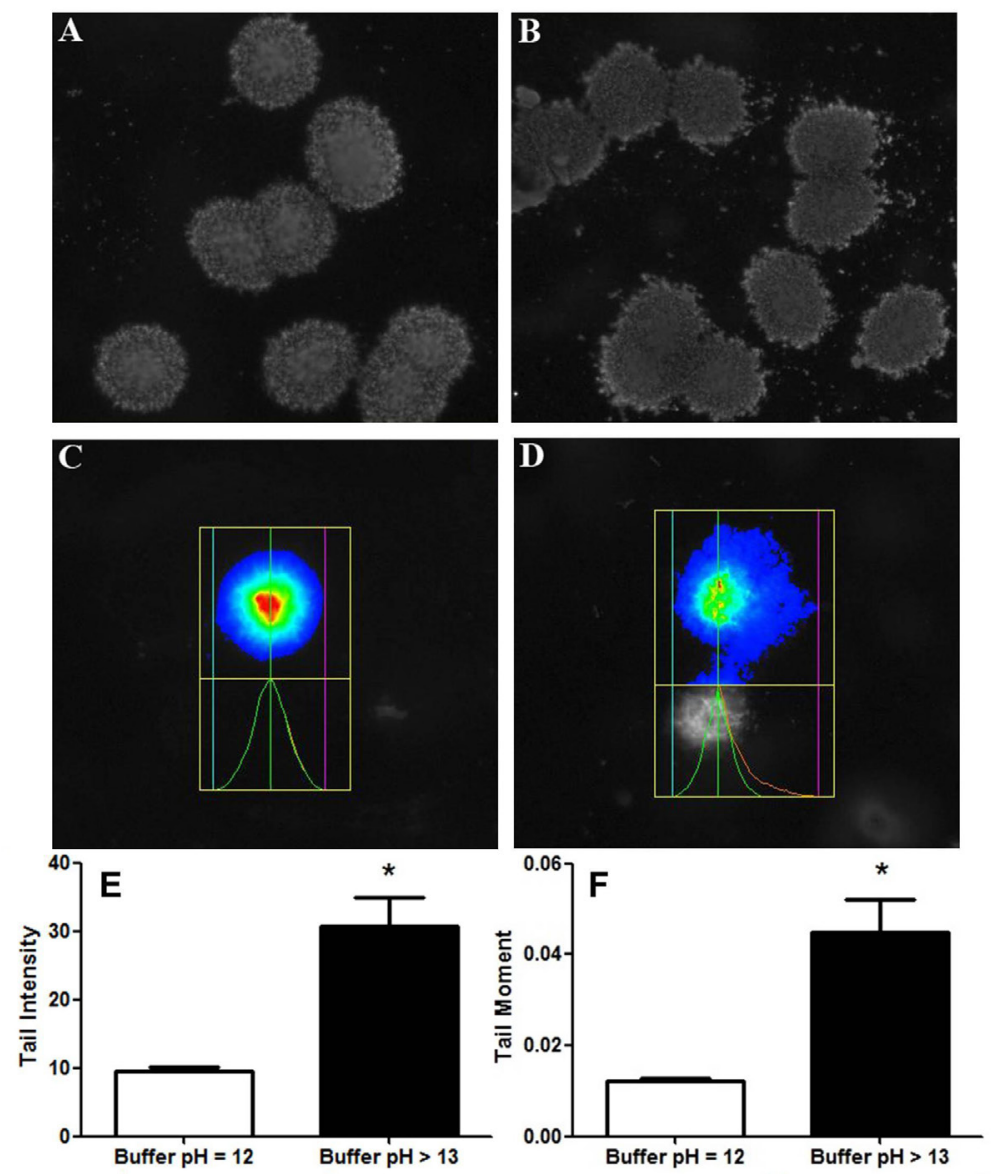

Figure 2. DNA damage evaluation in undifferentiated mesenchymal cells using the comet assay. Cells in buffer $\mathrm{pH}$ $=12(\mathbf{A})$ and $\mathrm{pH}>13(\mathbf{B})$; software analysis of cells in $\mathrm{pH}=12(\mathbf{C})$ and $\mathrm{pH}>13(\mathbf{D})$. E. Graphic representing the damage quantification by the two comet versions, obtained by the tail intensity data (Student $t$-test, $\mathrm{P}<0.0006$ ). F. Graphic representing the damage quantification by the two comet versions, obtained by the tail moment data (Student $t$-test, $\mathrm{P}=0.0013$ ). Images (A-D) were obtained at 40X magnification. 


\section{DISCUSSION}

Maintaining the genomic stability of stem cells in in vitro procedures is of great interest for cell therapy, as it can guarantee the quality of the cells. Furthermore, it is essential for selfrenewal processes as well as for differentiation into other cell types (Park and Gerson, 2005).

Cells undergoing changes in their in situ or in vitro microenvironment are exposed to endogenous and exogenous damage. However, damage is generally not fixed in the cell genome because DNA repair pathways are able to recognize and remove it, so that there are no deleterious effects (Peterson and Cote, 2004; Sancar et al., 2004; Houtgraaf et al., 2006; Shrivastav et al., 2008; Pardo et al., 2009). If the damage is not repaired, the cell utilizes a complex signaling pathway that might lead to apoptosis and/or senescence if cell division, cell maintenance, and/or maintenance of the cell's descendants are not feasible. Therefore, there would be a decreased tendency to undergo transformation that would lead to tumorigenesis (Andressoo et al., 2006; Wilson and Bohr, 2007).

In in vivo studies, somatic cells undergo about $10^{-4}$ mutations, and this high rate of change in the DNA is incompatible with involvement in organogenesis and morphogenesis processes. Thus, it would appear that embryonic stem cells are less susceptible to DNA change or have efficient defense mechanisms against different forms of damage, including genetic or genomic changes (Efroni et al., 2008; Maynard et al., 2008; Frosina, 2009). It is assumed that adult stem cells also have different DNA repair mechanisms that are more efficient than other somatic cells (Frosina, 2009). Despite this assertion, there is no guarantee that changes in the cellular microenvironment, in particular during the clonal expansion of adult stem cells, do not impact genomic integrity, and therefore, that transplantation of these cells is safe for therapeutic use. Faced with this dilemma, it is necessary to develop and standardize biological assays that are able to predict and/or assist in understanding and ensuring the safety of the procedures applied to cell therapy.

In this study, the isolation, characterization, and investigation of genomic integrity were performed in MSCs from rabbit adipose tissue using the comet assay. This assay has high sensitivity and is widely used to assess DNA damage. Two versions of the assay were tested, since each version is able to detect different types of DNA damage types. The $\mathrm{pH}>$ 13 alkaline version detects damage in the form of single-strand breaks, double alkali-labile sites, cross-linking, and loss of excision repair. This version is the most comprehensive, and in addition to detecting direct damage, it enables the evaluation of indirect damage such as lesions like methylation adducts, which are alkali-labile and expressed as simple breaks under high alkaline conditions (Singh, 2000; Tice et al., 2000). The other version $(\mathrm{pH}=12)$ detects mainly single- and double-strand breaks (Tice et al., 2000; Baumgartner et al., 2009).

Using these methods, the results obtained in this experiment highlighted the occurrence of MSC damage, which was more significant following utilization of the $\mathrm{pH}>13$ assay version. The results suggested that this damage occurs mainly from alkali-labile sites converted into single-strand breaks. Therefore, the MSCs appeared to be sensitive to elevated $\mathrm{pH}$, which causes DNA denaturation and leads to breaks in alkali-labile sites. Thus, it is suggested that MSC cultivation as well as their use in experimentation with techniques involving different $\mathrm{pH}$ or cellular $\mathrm{pH}$ variation require especially careful handling in order to obtain accurate results, as MSCs are potentially more sensitive to damage than are other somatic cells. This result can also be inferred from immortalized cells in culture (Oliveira et al., 2007; Priestley et al., 2010) and primary culture cells such as peripheral blood lymphocytes (Osipov et al., 
2014; Timoroglu et al., 2014). In circulating blood samples (Grassi et al., 2007; Braz et al., 2011; Costa et al., 2011; Kasuba et al., 2012), for example, it is not common to find damage frequently, which may also occur due to clonal expansion, when the $\mathrm{pH}>13$ comet assay version is used.

Studies in which an automatic analysis system is used to determine DNA damage using the comet assay show limited parameters such as only the DNA percentage in the tail (Osipov et al., 2014) or the tail intensity (Priestley et al., 2010; Braz et al., 2011; Costa et al., 2011; Camargo et al., 2013; Valença-Silva et al., 2014), or this parameter is associated with others, such as tail moment and tail length, in the results (Grassi et al., 2007; Kasuba et al., 2012; Aydin et al., 2013; Pant et al., 2014; Timoroglu et al., 2014). However, there is still no consensus regarding the best parameter for MSCs or other biological samples. With the advent of software, the tail intensity variable has been primarily used in publication, and some authors use such data as being synonymous for DNA percentage in the tail (Priestley et al., 2010; Braz et al., 2011; Costa et al., 2011; Valença-Silva et al., 2014). In this study, we decided to use both the tail intensity and tail moment variables, since Vieira et al. (2014) report that such variables might differ in MSCs. In their study, Vieira et al. (2014) stated that the tail moment analysis showed no statistically significant variations, whereas the tail intensity showed a high frequency of damage. They suggested using caution with cell therapy, considering that the number of passages is directly proportional to the exposure time of the MSC clonal expansion process.

Froelich et al. (2013) performed in vitro expansion of MSCs over ten passages and the cells from passages $1,2,3,5$, and 10 were used for the comet assay in a $\mathrm{pH}>13$ alkaline version. They asserted that there was no directly proportional relationship between the damage levels and the comet assay passages; in others words, the increase of damage in the clonal expansion length. However, unlike the aforementioned authors, Fuchs et al. (2012), using the $\mathrm{pH}>13$ comet assay version, obtained results in which the increase in the number of passages coincided with increased frequency of DNA damage.

Froelich et al. (2013) also detected chromosomal aberrations by means of the chromosomal aberration test, even when the comet assay did not detect damage. This same finding is also reported by Nikitina et al. (2011) and Bochkov et al. (2006).

The results from the experiments in this paper indicate the need for genetic tests that support the clonal expansion safety procedures for stem cell-based therapy, and they must be implemented as part of the safety evaluation. Furthermore, the results show that if the comet assay is the technique chosen for assessing genome integrity, the $\mathrm{pH}=12$ version would be indicated for use rather than the $\mathrm{pH}>13$ protocol, because it has been found that the latter is able to induce genomic damage. Thus, the standardization and establishment of a battery of tests are required, even before proceeding to promote MSC transplantation as a therapeutic modality in the era of regenerative medicine.

\section{ACKNOWLEDGMENTS}

We are grateful to Laboratório de Nutrigenômica e Toxicogenômica, Faculdade de Ciências Agronômicas, Universidade Estadual Paulista, Botucatu, Brazil, and to Professor Dr. Daisy Maria Favero Salvadori and Renato Paschoal Prado for their support in the comet assay analyses. Larissa Correa Hermeto was sponsored by Conselho Nacional de Desenvolvimento Cientifico e Tecnológico (CNPq) and Renata Matuo was awarded with a scholarship from Coordenação de Aperfeiçoamento de Pessoal de Nível Superior (CAPES). 


\section{REFERENCES}

Andressoo JO, Hoeijmakers JH and Mitchell JR (2006). Nucleotide excision repair disorders and the balance between cancer and aging. Cell Cycle 5: 2886-2888.

Aydin S, Bacanli M, Taner G, Sahin T, et al. (2013). Protective effects of resveratrol on sepsis-induced DNA damage in the lymphocytes of rats. Hum. Exp. Toxicol. 32: 1048-1057.

Baumgartner A, Cemeli E and Anderson D (2009). The comet assay in male reproductive toxicology. Cell Biol. Toxicol. 25: 81-98.

Bochkov NP, Voronina ES, Kosyakova NV, Liehr T, et al. (2007). Chromosome variability of human multipotent mesenchymal stromal cells. Bull. Exp. Biol. Med. 143: 122-126.

Braz MG, Mazoti MA, Giacobino J, Braz LG, et al. (2011). Genotoxicity, cytotoxicity and gene expression in patients undergoing elective surgery under isoflurane anaesthesia. Mutagenesis 26: 415-420.

Camargo EA, da Silva GN, Gobette CP, Marcondes JP, et al. (2013). No relationship between the amount of DNA damage and the level of hMLH1 and RASSF1A gene expression in bladder cancer cells treated with cisplatin and gemcitabine. Asian Pac. J. Cancer Prev. 14: 5941-5948.

Costa CA, Bidinotto LT, Takahira RK, Salvadori DM, et al. (2011). Cholesterol reduction and lack of genotoxic or toxic effects in mice after repeated 21-day oral intake of lemongrass (Cymbopogon citratus) essential oil. Food Chem. Toxicol. 49: 2268-2272.

Efroni S, Duttagupta R, Cheng J, Dehghani H, et al. (2008). Global transcription in pluripotent embryonic stem cells. Cell Stem. Cell 2: 437-447.

Froelich K, Mickler J, Steusloff G, Technau A, et al. (2013). Chromosomal aberrations and deoxyribonucleic acid singlestrand breaks in adipose-derived stem cells during long-term expansion in vitro. Cytotherapy 15: 767-781.

Frosina G (2009). DNA repair in normal and cancer stem cells, with special reference to the central nervous system. Curr. Med. Chem. 16: 854-866.

Fuchs R, Stelzer I, Drees CM, Rehnolt C, et al. (2012). Modification of the alkaline comet assay with human mesenchymal stem cells. Cell Biol. Int. 36: 113-117.

Grassi TF, Camargo EA, Salvadori DM, Marques ME, et al. (2007). DNA damage in multiple organs after exposure to chlorhexidine in Wistar rats. Int. J. Hyg. Environ. Health 210: 163-167.

Houtgraaf JH, Versmissen J and van der Giessen WJ (2006). A concise review of DNA damage checkpoints and repair in mammalian cells. Cardiovasc. Revasc. Med. 7: 165-172.

Kasuba V, Rozgaj R, Milic M, Zeljezic D, et al. (2012). Evaluation of genotoxic effects of lead in pottery-glaze workers using micronucleus assay, alkaline comet assay and DNA diffusion assay. Int. Arch. Occup. Environ. Health 85: 807-818.

Mackay AM, Beck SC, Murphy JM, Barry FP, et al. (1998). Chondrogenic differentiation of cultured human mesenchymal stem cells from marrow. Tissue Eng. 4: 415-428.

Maynard S, Swistowska AM, Lee JW, Liu Y, et al. (2008). Human embryonic stem cells have enhanced repair of multiple forms of DNA damage. Stem. Cells 26: 2266-2274.

Mesimäki K, Lindroos B, Tornwall J, Mauno J, et al. (2009). Novel maxillary reconstruction with ectopic bone formation by GMP adipose stem cells. Int. J. Oral. Maxillofac. Surg. 38: 201-209.

Nikitina VA, Chausheva AI, Zhanataev AK, Osipova EY, et al. (2011). Assessment of DNA damage in human bone marrow cells and multipotent mesenchymal stromal cells. Bull. Exp. Biol. Med. 151: 550-552.

Oliveira RJ, Matuo R, da Silva AF, Matiazi HJ, et al. (2007). Protective effect of beta-glucan extracted from Saccharomyces cerevisiae, against DNA damage and cytotoxicity in wild-type (k1) and repair-deficient (xrs5) CHO cells. Toxicol. In Vitro 21: 41-52.

Osipov AN, Smetanina NM, Pustovalova MV, Arkhangelskaya E, et al. (2014). The formation of DNA single-strand breaks and alkali-labile sites in human blood lymphocytes exposed to 365-nm UVA radiation. Free Radic. Biol. Med. 73: 34-40.

Pant K, Springer S, Bruce S, Lawlor T, et al. (2014). Vehicle and positive control values from the in vivo rodent comet assay and biomonitoring studies using human lymphocytes: Historical database and influence of technical aspects. Environ. Mol. Mutagen. 55: 633-642.

Pardo B, Gomez-Gonzalez B and Aguilera A (2009). DNA repair in mammalian cells: DNA double-strand break repair: how to fix a broken relationship. Cell Mol. Life Sci. 66: 1039-1056.

Park Y and Gerson SL (2005). DNA repair defects in stem cell function and aging. Annu. Rev. Med. 56: 495-508.

Peterson CL and Cote J (2004). Cellular machineries for chromosomal DNA repair. Genes Dev. 18: 602-616.

Pittenger MF, Mackay AM, Beck SC, Jaiswal RK, et al. (1999). Multilineage potential of adult human mesenchymal stem cells. Science 284: 143-147. 
Priestley CC, Green RM, Fellows MD, Doherty AT, et al. (2010). Anomalous genotoxic responses induced in mouse lymphoma L5178Y cells by potassium bromate. Toxicology 267: 45-53.

Qin Y, Ji H, Wu Y and Liu H (2009). Chromosomal instability of murine adipose tissue-derived mesenchymal stem cells in long-term culture and development of cloned embryos. Cloning Stem. Cells 11: 445-452.

Sancar A, Lindsey-Boltz LA, Unsal-Kacmaz K and Linn S (2004). Molecular mechanisms of mammalian DNA repair and the DNA damage checkpoints. Annu. Rev. Biochem. 73: 39-85.

Shrivastav M, De Haro LP and Nickoloff JA (2008). Regulation of DNA double-strand break repair pathway choice. Cell Res. 18: 134-147.

Singh NP (2000). Microgels for estimation of DNA strand breaks, DNA protein crosslinks and apoptosis. Mutat. Res. 455: 111-127.

Tice RR, Agurell E, Anderson D, Burlinson B, et al. (2000). Single cell gel/comet assay: guidelines for in vitro and in vivo genetic toxicology testing. Environ. Mol. Mutagen. 35: 206-221.

Timoroglu I, Yuzbasioglu D, Unal F, Yilmaz S, et al. (2014). Assessment of the genotoxic effects of organophosphorus insecticides phorate and trichlorfon in human lymphocytes. Environ. Toxicol. 29: 577-587.

Torsvik A, Rosland GV, Svendsen A, Molven A, et al. (2010). Spontaneous malignant transformation of human mesenchymal stem cells reflects cross-contamination: putting the research field on track - letter. Cancer Res. 70: 6393-6396.

Valença-Silva G, Braz MG, Barreto RE and Salvadori DMF (2014). Low dose of the anesthetic propofol does not induce genotoxic or mutagenic effects in Nile tilapia. Trans. Am. Fish. Soc. 143: 414-419.

Vieira MHC, Oliveira RJ, Eça LPM and Hermeto LC (2014). Therapeutic potential of mesenchymal stem cells to treat Achilles tendon injuries. Genet. Mol. Res. 13: 10434-10449.

Villaron EM, Almeida J, Lopez-Holgado N, Alcoceba M, et al. (2004). Mesenchymal stem cells are present in peripheral blood and can engraft after allogeneic hematopoietic stem cell transplantation. Haematologica 89: 1421-1427.

Villela IV, de Oliveira IM, Silveira JC, Dias JF, et al. (2007). Assessment of environmental stress by the micronucleus and comet assays on Limnoperna fortunei exposed to Guaiba hydrographic region samples (Brazil) under laboratory conditions. Mutat. Res. 628: 76-86.

Wilson DM, III and Bohr VA (2007). The mechanics of base excision repair, and its relationship to aging and disease. DNA Repair 6: 544-559.

Zuk PA, Zhu M, Mizuno H, Huang J, et al. (2001). Multilineage cells from human adipose tissue: implications for cellbased therapies. Tissue Eng. 7: 211-228. 